\title{
Testis Development and Differentiation in Amphibians
}

\author{
Álvaro S. Roco (D), Adrián Ruiz-García and Mónica Bullejos *D \\ Departamento de Biología Experimental, Facultad de Ciencias Experimentales, Campus Las Lagunillas S/N, \\ Universidad de Jaén, 23071 Jaén, Spain; asroco@ujaen.es (Á.S.R.); arg00027@red.ujaen.es (A.R.-G.) \\ * Correspondence: bullejos@ujaen.es; Tel.: +34-953-212770
}

Citation: Roco, Á.S.; Ruiz-García, A.; Bullejos, M. Testis Development and Differentiation in Amphibians. Genes 2021, 12, 578. https://doi.org/ 10.3390/genes12040578

Academic Editor: Francisco Javier Barrionuevo Jimenez

Received: 26 February 2021

Accepted: 14 April 2021

Published: 16 April 2021

Publisher's Note: MDPI stays neutral with regard to jurisdictional claims in published maps and institutional affiliations.

Copyright: (c) 2021 by the authors. Licensee MDPI, Basel, Switzerland. This article is an open access article distributed under the terms and conditions of the Creative Commons Attribution (CC BY) license (https:// creativecommons.org/licenses/by/ $4.0 /)$.

\begin{abstract}
Sex is determined genetically in amphibians; however, little is known about the sex chromosomes, testis-determining genes, and the genes involved in testis differentiation in this class. Certain inherent characteristics of the species of this group, like the homomorphic sex chromosomes, the high diversity of the sex-determining mechanisms, or the existence of polyploids, may hinder the design of experiments when studying how the gonads can differentiate. Even so, other features, like their external development or the possibility of inducing sex reversal by external treatments, can be helpful. This review summarizes the current knowledge on amphibian sex determination, gonadal development, and testis differentiation. The analysis of this information, compared with the information available for other vertebrate groups, allows us to identify the evolutionarily conserved and divergent pathways involved in testis differentiation. Overall, the data confirm the previous observations in other vertebrates-the morphology of the adult testis is similar across different groups; however, the male-determining signal and the genetic networks involved in testis differentiation are not evolutionarily conserved.
\end{abstract}

Keywords: amphibian; sex determination; gonadal differentiation; testis; sex reversal

\section{Introduction}

The class Amphibia includes 8301 species in three orders, with distinct representation and anatomical features: $88 \%$ Anura (frogs and toads), 9\% Caudata (salamanders and tritons), and 3\% Gymnophiona (caecilians, or limbless amphibians) [1]. Despite their worldwide decline, new species are discovered every year $(60 \%$ increase in the number of species since 1985) [1].

Amphibians constitute an interesting group in which reproductive successful hybrids can be produced, and polyploidy (natural or artificial) is well tolerated. Natural polyploids have been described in 15 anuran and four urodelan families, whereas (to the best of our knowledge) no polyploid species have been identified in caecilians (for a thorough review on amphibian polyploid species, see [2]). True parthenogenesis does not exist in this class, but there are examples of unisexual and bisexual species reproducing by hybridogenesis (Pelophylax kl. esculentus [3]), kleptogenesis (unisexual salamanders of the genus Ambystoma [4]), gynogenesis (induced [5,6], not demonstrated in nature), and preequalizing hybrid meiosis (Bufo pseudoraddei baturae [7]). Amphibians show developmental plasticity in response to environmental conditions [8] and a great variety of reproductive modes [9]. Their development includes an embryonic period and a larval phase that ends in metamorphosis. The majority of amphibian species are oviparous, with the eggs developing in a wide range of environments (e.g., water, foam, plants, or even in the back or the stomach of the adults). Viviparous and ovoviviparous species exist, mainly in urodelan and caecilians, with the eggs developing in the oviducts. These characteristics can be beneficial for research, but can also impair the analysis of gonadal development in this clade.

In this review we will cover the process of testis development in amphibians, from the appearance of the gonad in the body cavity to testis differentiation at metamorphosis. Testis 
differentiation in juvenile and adults in the class Amphibia is thoroughly covered in [10]. Before starting with gonadal development, we have included one section about the sex chromosomes and sex-determining genes in this group, highlighting those characteristics that hinder the analysis of gonadal development and differentiation.

\section{Amphibian Sex Chromosomes and Sex Determination}

\subsection{Sex Chromosomes}

In general, the males are the heterogametic sex in mammals $(X X / X Y)$, whereas, in birds, it is the females $(Z Z / Z W)$. The situation in amphibians is not as simple. Both male $(\mathrm{XX} / \mathrm{XY})$ and female $(\mathrm{ZZ} / \mathrm{ZW})$ heterogamety can be found in this class, and transitions between the same or different sex chromosome systems are identified even in closely related species (e.g., the family Ranidae [11], the genus Xenopus [12,13], and the genus Bufo [14]). Other combinations are also possible, like systems with multiple sex chromosomes [15-17], with the extreme example of the six pairs of sex chromosomes described in Leptodactylus pentadactylus [18], or the 00/W0 female heterogamety identified in Leiopelma hochstetteri [19]. To further complicate the situation, most amphibian species have homomorphic sex chromosomes (for a review, see [20-22]). According to The Tree of Sex Consortium [23], the sex chromosomes have been analyzed in about $2 \%$ of amphibian species (114 Anura, 58 Caudata and 1 Gymnophiona), identifying sex chromosome heteromorphism in $38 \%$ of the analyzed species (17\% in Anura, $45 \%$ in Caudata and in the only Gymnophiona analyzed) [23].

The identification of the sex chromosome system operating in one species is not straightforward if the sex chromosomes are homomorphic. In that case, this information can be obtained by analyzing the sex ratio in the offspring produced by gynogenesis, or from crosses that involve sex-reversed individuals (e.g., Pleurodeles waltl [24] and Xenopus laevis $[25,26])$. These results are not always straightforward, and bizarre sex ratios may reveal non common sex-determining mechanisms. This is the case of the frog Fejervarya kawamurai, where a multifactorial complementary sex determination has been proposed [27]. With the advent of genome sequencing strategies, sex-linked markers (and sex heterogamety) have been identified in a growing number of amphibian species. These markers reveal a lack of conservation in the sex chromosomes in this group and show that specific chromosomes have evolved independently as sex chromosomes in different lineages. These "preferred" sex chromosomes harbour sex-related genes like $d m r t 1$, sox3, ar, and foxl2 [11,28-31].

Geographical variations in sex chromosomes have been described in single species (e.g., Rana temporaria [32,33], Glandirana rugosa [34,35], and Xenopus tropicalis [36]) and should be taken into account when analyzing gonadal development, since different populations can have different sex-determining genes. The most extreme example occurs in G. rugosa, in which six geographic variants with both XX/XY and ZZ/ZW sex chromosomes evolved after two independent chromosomal inversions followed by hybridization events [37-42]. Another example of intraspecies variation occurs in the amphibian model $X$. tropicalis, a species with three sex chromosomes $(Y>W>Z)$ coexisting in laboratory strains [36] and in natural populations [43], which likely originated after the emergence of a $\mathrm{Y}$ chromosome from an ancestral $\mathrm{Z}$ chromosome [43].

\subsection{Sex Determination}

Amphibian sex determination is presumed to be controlled genetically [34,44-48]. However, it is also evident that environmental cues, such as temperature or steroid hormones, can override genetic sex determination, producing sex reversal [49-51]. Sexual steroids, estrogens, and androgens can easily induce sex reversal (for a review, see $[45,49,50]$ ). On the other hand, though thermal effects on sex determination have been considered anecdotal under natural conditions [45], high and low temperatures can induce sex reversal in anuran and urodelan species (e.g., Rana chensinensis [52], Quasipaa spinose [53], Fejervarya limnocharis [54], Xenopus polyploid hybrids [55], Hynobius retardatus [56], 
P. waltl [24], Pleurodeles poireti [57], Triturus cristatus [58], and Triturus carnifex [50]) (for a recent review, see [59]). The implication of environmental factors in sex reversal in natural populations of amphibians has been underscored, likely due to the lack of knowledge regarding the sex chromosomes or the sex-determining genes in most amphibian species. Indeed, the increasing number of molecular sex-linked markers suggests that sex reversal may be more common than suspected in amphibians (sex-reversed individuals have been described in natural populations of the species Rana clamitans [60] and R. temporaria [61]).

The genes involved in sex determination in amphibians are largely unknown, partly due to the difficulty in identifying the sex chromosomes in most species. In addition, homomorphic sex chromosomes facilitate the rapid turnover of sex-determining genes [62] This could explain why so many different sex-determining genes have been identified in fish (dmy, Sdy, Gsdfy, Sox3y, amhy, amhr2y, Dmrt1, and gsdf6y (for a review, see [63,64])), a group also characterized by a high frequency of homomorphic sex chromosomes, and foreshadows a similar situation in amphibians $[65,66]$.

The only sex-determining gene known in this class, the $d m-w$ gene, is also the only $\mathrm{W}$-linked sex-determining gene identified in vertebrates [67]. It was first described in $X$. laevis, an allotetraploid species with homomorphic ZZ/ZW sex chromosomes [68,69], which originated after the hybridization of two ancestral species (genomes $L$ and $S$ ) with $2 \mathrm{n}=18$ chromosomes each $(2 \mathrm{n}=4 \mathrm{x}=36$, LLSS) [70]. The $d m-w$ gene evolved from a partial duplication of $d m r t 1 . S$ (on chromosome 1S), occurring after allotetraploidization [71,72]. $d m-w$ shows specific expression in ZW bipotential gonads, and its role in X. laevis sex determination was confirmed by functional analysis. The overexpression of $d m-w$ can induce female differentiation in ZZ tadpoles, whereas $d m-w$ knockdown can cause femaleto-male sex reversal in ZW larvae $[67,73]$. The precise mechanism of action of $d m-w$ is still unknown. It has been proposed that Dm- $w$ functions as a dominant-negative form of Dmrt1 (lacking the transactivation domain), antagonizing the testis formation promoted by Dmrt1 and resulting in a high expression of cyp19a1 and foxl2 [74].

$d m-w$ is present in other species of the genus Xenopus (though not in X. tropicalis) [13,72], but its involvement in sex determination in these species has not yet been experimentally confirmed. In those species in which $d m$ - $w$ is not completely female-specific, this gene may be a weak determining gene, or not necessary to determine female development [13]. In addition, species with a female-specific $d m-w$ gene may have differences in their sexdetermining pathways. This is likely the case in X. laevis and X. gilli, two species with the same chromosome number $(2 \mathrm{n}=4 \mathrm{x}=36)$ that can hybridize in nature [75-77]. Both species have a $\mathrm{ZZ/ZW}$ sex chromosome system and a female-specific $d m-w$ gene $[13,72]$. There is no information regarding the sex-determining ability of $d m-w$ in $X$. gilli, but the sex ratios of polyploid hybrids show that the sex-determining pathways may not be equivalent in both species (the frequency of males with $\mathrm{W}^{\mathrm{L}} \mathrm{ZZ}$ genotypes depends on the species that provided the $Z$ chromosomes) [55,78].

No other sex-determining gene has been identified in amphibians. Several lines of evidence have proposed a critical role of the androgen receptor (ar) as a male-determining gene in G. rugosa $[79,80]$, although functional experiments do not fully corroborate this role $[30,81]$. Thus, it remains unclear which gene is required for sex determination in this species. The existence of different sex-determining loci in different populations should be also taken into account, since they can provide an explanation for the 1:1 sex ratios observed among the $\mathrm{XZ}$ offspring of crosses between $\mathrm{XX}$ females and $\mathrm{ZZ}$ males from different populations [82].

Autosomal factors may also be involved in sex determination in amphibians (i.e., F. kawamurai) [27]. This could be the case for the Japanese frog Buergeria buergeri, a species with heteromorphic ZZ/ZW sex chromosomes [83] where triploid ZZW individuals $(\mathrm{n}=80)$ can be either male (53.8\%) or female (46.2\%) [84]. An alternative explanation could be that sexual differentiation proceeds randomly in either the male or female direction if one $\mathrm{W}$ and two $\mathrm{Z}$ chromosomes cannot tilt the balance toward the male or the female pathway in ZZW individuals [85]. 


\section{Gonadal Development and Differentiation in Amphibians}

\subsection{General Considerations}

The general model of gonad development appears to be universal for all vertebrates. However, variations in particular vertebrate groups, or even in species, are evident. In amphibians, gonadal formation takes place during the larval stages; however, not all amphibian species have differentiated gonads at metamorphosis, as the development of testes and ovaries progresses at different paces in different species [86]. The rates of gonadal differentiation vary considerably among species and sexes. Depending on the stage of differentiation at metamorphosis, three rates can be established in the ovaries: the basic rate (ovarian cavity appears at the end of metamorphosis), delayed rate (the first diplotenic oocytes arise after metamorphosis), and accelerated rate (pre-vitellogenic oocytes appear before metamorphosis) [87]. Correspondingly, three rates can also be considered during testicular development based on the timing of the differentiation of seminiferous tubules: the basic rate (during metamorphosis), delayed rate (after metamorphosis), and accelerated rate (before metamorphosis) [88].

Undifferentiated gonads in most amphibian species differentiate directly into ovaries or testes. This pattern of gonadal differentiation has been called differentiated or undifferentiated, depending, respectively, on the simultaneous or delayed differentiation of the testes compared with the ovaries [89]. In certain species or populations (sexually undifferentiated races, according to [90]), it has been reported that undifferentiated gonads of both sexes undergo a secondary undifferentiated condition of ovarian type before gonadal differentiation. In this pattern of gonadal differentiation (called semi-differentiated by Gramapurohit [89]), testes will develop in males after oocyte degeneration. A semidifferentiated pattern has been described in several anuran species (e.g., Rana sylvatica, Rana dalmatina, Rana latastei, Rana curtipes, and Rachophorus arboreus [91] and the references therein). It has been argued that undifferentiated testes in amphibians do not go through an ovary-like transition phase $[87,92]$. However, the existence of this transition phase cannot be completely ruled out, considering the information available on undifferentiated races (sensu Witschi) $[93,94]$. In addition, a similar condition (called "juvenile hermaphroditism") was described in zebrafish (Danio rerio [95]) and black tetra (Gymnocorymbus ternetzi [96]). In these species, during gonadal development, most individuals develop undifferentiated ovary-like gonads [97,98]. The transformation of these gonads into testes is characterized, as in amphibians, by the apoptosis of early diplotenic oocytes [97]. The apoptosis of oocytes could be triggered by a decrease in aromatase, as lower levels of aromatase were detected in early diplotenic oocytes from undifferentiated ovary-like gonads changing to testes [97]. This possibility is supported by the results obtained after treatment with fadrozole, as this aromatase inhibitor induces oocyte apoptosis and female-to-male sex reversal [97,99]. In this regard, it would be of interest to analyze the expression pattern of the genes involved in gonadal differentiation in species with an alleged semi-differentiated pattern. In this way, it would be possible to check if the initiation of the female pathway takes place in these species before the onset of the male pathway.

\subsection{Sexually Undifferentiated Gonad}

3.2.1. Germ Cell Specification

Germ cells constitute an essential part of the gonad, although they originate outside it. Two modes of germ cell specification exist in animal embryos [100], and both can be found in amphibians [101]. In anurans, primordial germ cells (PGCs) have an endodermal origin and are specified through preformation/inheritance, as a consequence of the localization in the egg of maternally inherited germ cell determinants (germ plasm) [102]. In urodeles, the PGCs are of mesodermal origin and the segregation of the germ cell lineage among somatic cells occurs as it does in mammals, through cell-cell interactions (inducing signals secreted by embryonic tissues) $[103,104]$. In Gymnophiona, the PGCs are located at a young stage in the endoderm [105], although not much is known about their specification. 
Inductive germ cell determination is likely an ancestral mode of germ cell specification, whereas inherited specification is a derived mechanism that evolved through convergence. Thus, the acquisition of the germ plasm must have evolved independently in several lineages of vertebrate embryos, including anurans. The evolutionary cause for the convergence of the germ plasm is still under debate $[100,106]$.

\subsubsection{Initial Gonadal Formation}

In amphibians, the presumptive gonads originate from two longitudinal thickenings of the celomic epithelium, localized on the ventral part of the mesonephros along both sides of the gut mesentery (reviewed in $[45,49,92,105])$. As in other vertebrate species, primordial germ cells (PGC) of extragonadal origin invade the gonadal anlagen, forming undifferentiated gonads composed of germ and somatic cells. In some amphibian species, genital ridges only become evident when the PGCs arrive at the presumptive gonad (e.g., Bombina orientalis [107], X. laevis [108], and Bombina variegata [109]). However, genital ridges can develop independently of germ cells, as sterile gonads can differentiate in the absence of these cells (e.g., X. laevis [110,111], Xenopus hybrids [112], P. waltl [113]).

Initially, the gonads are bipotential and no histological differences between sexes can be identified [49]. The bipotential gonads in amphibians differ from those of birds and reptiles by the absence of primitive sex cords (for a review, see [114]). However, as in birds and reptiles, they are compartmentalized into two domains: the cortex, formed by somatic cells and gonia, and the medulla, formed only by somatic cells (e.g., Bufo bufo [91], $R$. nigromaculata [115]). The presence of these two domains is common in amphibians, although the onset of their separation is species-specific (e.g., B. orientalis [107], B. variegata [109], Ambystoma mexicanum [116], and caecilians [105], reviewed in [92]), and independent of the presence of germ cells [110].

\subsection{Sexual Differentiation of the Testis \\ 3.3.1. Morphological Changes}

The fate of the bipotential gonad is established during sex determination. Despite the lack of conservation in the sex-determining gene in this group, one of the first morphological signs of sexual differentiation, the change in the localization of the germ cells in males, is quite conserved. In the differentiating testes, the germ cells migrate from the cortex into the medulla, where they interact with differentiating Sertoli cells (precursor Sertoli cells) and peritubular myoid cells, forming cysts. Thus, developing testes are easily distinguishable due to the lack of a clear compartmentalization into the cortex and medulla: the sterile cortex becomes a thin layer that surrounds the gonad (the tunica albuginea), whereas the germ cells (spermatogonia) are distributed through the entire gonad (e.g., B. bufo [91], Rana nigromaculata [115], X. laevis [117], R. temporaria, Hyla arborea and Pelophylax lessonae [118], and P. waltl [104]). In the differentiating ovaries, oogonia remain in the cortex, where they proliferate and form follicles when surrounded by somatic cells, whereas a medulla without germ cells forms in the center of the gonad. Soon after the onset of differentiation in the ovary, the medulla is completely modified, with medullary cells losing cell junctions and resulting in the formation of ovarian cavities, which are absent in the testes (e.g., B. bufo [91], R. nigromaculata [115], X. laevis [117], and P. waltl [104]); for a review, see [92].

Depending on the species, the germ cells and their migration from the cortex to the medulla are not required for testis cord formation or for testis differentiation (e.g., X. laevis [110], Xenopus hybrids [112], P. waltl [113]). However, germ cells may play important roles in the development of the ovaries and the maintenance of the ovarian structures. In fact, ZW tadpoles from X. laevis develop male gonads when their germ cell number is reduced after knocking down the germ cell-specific form of $d m r t 1 . L$ [119].

The origin of the somatic cells of the gonads is controversial in amphibians [45,49]. Ultrastructural analysis has suggested that somatic cells in both the seminiferous cords and follicles are derived from the celomic epithelium $[91,93,109,115,120,121]$. The origin of the 
medulla is less evident. It has been proposed that the mesonephric blastema $[104,122]$ or the interrenal gland [123] contribute cells to the medulla. However, most studies state that, in anurans, the medulla is derived from the celomic epithelium (e.g., B. bufo [91], Rhacophorus arboreus [93], B. variegata [109], R. nigromaculata [115], Rana pipiens and X. laevis [121]). The rete testis is formed from medullary cords near the hilus. Thus, it is not unusual that species that lack a sterile medulla during testicular differentiation also lack the rete testis (e.g., B. variegata [109]). Finally, mesenchymal cells and blood vessels migrate from the mesonephros into the gonads $[117,121]$. They are located between the cortex and the medulla, with basal lamina forming at the interface of the celomic epithelium-derived cells and the stromal cells. In this way, different gonadal structures are achieved in both sexes ([117] and the references therein).

\subsubsection{Cellular Mechanisms Involved in Testis Differentiation}

The development of the testis in vertebrates occurs through a series of common cellular mechanisms, although differences between groups or species are possible. The proliferation of Sertoli cell precursors is one of the first morphological differences observed between the sexes in mice [124], chickens [125], and turtles [126], indicating that it may be a conserved mechanism in vertebrate testis organogenesis [127]. Proliferation has been studied in a wide variety of anuran (X. laevis, [117], R. nigromaculata [120], G. rugosa [128]) and urodelan (A. mexicanum [116], P. waltl [129]) species. However, its role in testis differentiation in this class is not evident. The proliferative activity in undifferentiated amphibian gonads is more marked in the proximal regions, including the gonadal mesentery and medulla; however, no differences were observed between both sexes before differentiation began. In differentiated gonads, sex-specific cell proliferation patterns can be observed, with the testes showing somatic proliferation throughout the gonads, whereas proliferation occurs in proximal locations in developing ovaries [117,128].

Another cellular mechanism involved in testis differentiation in certain species is the migration of mesonephric cells into the gonads. Mesonephric cell migration is required for testis cord formation in mice $[130,131]$. However, cells migrating from the mesonephros do not appear to be necessary for testis cord formation in the sea turtle (Lepidochelys olivacea), as bipotential gonads separated from the mesonephros showed testis cord development [132]. The existence of primitive sex cords in the bipotential gonads in turtles, but not in mice, could explain the requirement of mesonephric cell migration for testis cord formation in mice, but not in turtles [126]. In fact, although male-specific mesonephric cell migration is conserved in both mice and chickens, its inhibition has no effect on the testis cord organization in chickens, a species that also retains primitive sex cords in undifferentiated gonads $[133,134]$. In amphibians, migration from the mesonephros occurs in both sexes, but only after gonadal differentiation $[117,122,128]$. Thus, differences in mesonephric migration in vertebrates (regarding (1) its onset, (2) its requirement for testis cord formation, and (3) the sex of the gonads where mesonephric cells migrate) may be the consequence of different requirements to form or maintain testis cords in developing gonads. This, in turn, could depend on (1) the presence or absence of primitive cords in bipotential gonads and (2) the presence or absence of compartmentation of undifferentiated gonads in the cortex and medulla. Investigating the requirement of mesonephric cell migration for the formation of testis cords in amphibian male gonads will provide information about the evolutionary dynamics of vertebrate testis differentiation.

\subsubsection{Germ Cell Differentiation: Spermatogenesis}

The sex of the germ cells depends on the sex of the developing gonads. In amphibians, as in all vertebrate groups, the onset of meiosis depends on the developmental pathway of the gonad. Germ cells enter meiosis in the larval ovary; however, meiosis is generally delayed until after metamorphosis in males $[87,88,135]$. Exceptions exist, and species have been described that produce sperm at the end of metamorphosis, including Pseudis paradox and Pseudis minuta [136,137]. 
The somatic cells, specifically Sertoli cells, are responsible for providing the correct environment for germ cell proliferation, meiosis, and sperm differentiation (spermatogenesis) [138,139] (for detailed reviews, see [140-142]). In vertebrates, two major types of spermatogenesis can be identified based on the structure of the basic unit where it takes place. In amniotes (mammals, birds, and reptiles), spermatogenesis occurs in the seminiferous tubules (non-cystic spermatogenesis), whereas in anamniotes (amphibians and fish) spermatogenesis takes place in cysts, a structure formed when Sertoli cells engulf a single spermatogonia stem cell (for a discussion about the cyst concept, see [143] and references therein).

Spermatogenesis in amphibians has been divided into prespermatogenesis and active spermatogenesis [144], in the same way it has been described for humans [145]. During prespermatogenesis the gonocytes (also called prespermatogonia or prospermatogonia [146]) proliferate in the developing testes of tadpoles, surrounded by pre-Sertoli cells. On the other hand, during active spermatogenesis, spermatogonial stem cells inside the cyst either proliferate (self-renewing the spermatogonial pool) or produce secondary spermatogonia that enter meiosis (primary and secondary spermatocytes), yielding round spermatids and then sperm $[10,144]$. According to this division, primary spermatogonia can be prespermatogonia (in larval testes, equivalent to gonocytes in mammals) or spermatogonial stem cells (in juvenile and adult testes), two cell types showing distinct ultrastructural morphology [144].

Information about amphibian spermatogenesis mostly cover active spermatogenesis (e.g., Pelophylax bedriagae [147], P. kl. esculentus [148], Salamandra salamandra [149]) or spermiogenesis (Odontophrynus cultripes [150], and Ambystoma dumerilii [151]), whereas prespermatogenesis has been only studied in P. lessonae and Pelophylax ridibundus [144]. For a detailed description of spermatogenesis in the three amphibian orders, see [10,152].

Sertoli cells differentiate and proliferate as the cyst grows and matures. The number of Sertoli cells forming a given cyst grows with the mitotic division of the germ cells. Once germ cells enter meiosis, proliferation ceases, coinciding with the formation of tight junctions and desmosomes between Sertoli cells (the testis barrier is formed). Once the spermiogenesis has finished, the cysts open to release spermatozoa during spermiation. In this process Sertoli cells degenerate in urodelan amphibians [140]. In anurans, the basal parts of the Sertoli cells remain after spermiation, later regenerating the Sertoli cells [153]. The transient germinal epithelium characteristic of cystic spermatogenesis requires the turnover of Sertoli cells. Sertoli cells can divide when they are in contact with mitotically active spermatogonia stem cells. In this way, new cysts are formed periodically. It has been hypothesized that a population of Sertoli stem cells must exist in amphibians, as it exists in the transition zone (where seminiferous tubules connect to the rete testis) in mammals [154], but evidence is still lacking [155]. Most data on the control of Sertoli cell proliferation come from observations in fish (e.g., Oreochromis niloticus [156,157], Clarias gariepinus [158], D. rerio [159]; for a review, see [141]). In this group two regulatory mechanisms of Sertoli cell proliferation have been described: (1) to generate new cysts (stimulated by thyroid hormone/FSH and estrogen through high levels of Igf3 and Pdecgf), and (2) during the development of existing cysts (activated by FSF and progestins through Igf3 and androgens produced by Leydig cells) [155]. The existence of equivalent regulatory pathways in amphibians must be corroborated experimentally.

The spermatogonial stem cells in the cyst proliferate by mitoses. Due to incomplete cytokinesis, cytoplasmic bridges keep germ cells connected (a characteristic widely conserved across animals). As a consequence, all the germ cells enclosed in one cyst are at the same developmental stage, although examples of asynchrony in the same cyst have been described (e.g., P. lessonae and P. ridibundus [144]). It has been proposed that the asynchrony could be due to the breakage of cytoplasmic bridges (e.g., due to cell death) or to the inclusion of two germ cells in the same cyst [144].

Spermatogenic efficiency (and the Sertoli supporting capacity) has been reduced over the course of vertebrate evolution [155]. The change from cystic to non-cystic spermatoge- 
nesis involves an increase in regulatory complexity in Sertoli cells (these cells provide a supporting environment for germ cells at different developmental stages at the same time, e.g., cells located in basal, medial, and adluminal regions of the seminiferous tubules) and a reduction in the Sertoli supporting capacity. On the other hand, cystic spermatogenesis supports the development of more spermatogonia, producing a higher amount of spermatozoa. In fact, the supporting capacity of Sertoli cells is 10 times higher in anamniotes than in mammals [155]. In this sense, greater attention should be paid to the effect of environmental contaminants on the supporting capacity of Sertoli cells in amphibians and on the fertility of these species.

\section{Testis Plasticity}

Most caudata are atypical regarding testis differentiation. In Salamandridae and Plethodontidae, males possess multi-lobulated testes that continue to differentiate during adult life [160]. In the differentiated testis of $P$. waltl, two regions can be identified: (1) the undifferentiated anterior region, a source of germ cells for the differentiated lobe, although it can also form a functional testis if the differentiated lobe is removed [160]; and (2) the first lobe, located in the posterior region of the developing gonad at the end of metamorphosis. New lobes can form periodically after the extrusion of spermatozoa and regression of the empty part of the testis. This triggers differentiation of adjacent Leydig cells and the formation of the glandular region in the last lobe. Quiescent germ cells present in the glandular region become spermatogonia and generate another testis lobe in the caudal position [160].

Another particularity of testis development in certain amphibian species (the Bufonidae family) is Bidder's organ [161-163], an ovary-like gonadal structure located at the most anterior part of male and female developing gonads (for a description of the morphological diversity of Bidder's organ and adult gonads in bufonids, see [162]). The development of Bidder's organ has been studied in several species and conditions (e.g., Bufo ictericus [164], B. bufo [161], Bufo woodhousii [165], and Rhinella schneideri [166]). This gonadal structure resembles ovarian tissue. In most species, no evident medulla and medullar cavity are observed (the medulla can be evident only during some developmental stages (e.g., B. bufo [161]). However, there are species with an identifiable cortex (with follicles at different stages of development) and medulla (with collagen fibers and blood vessels in some cases) (e.g., B. ictericus [164]). At pre-metamorphic stages, the oocytes in Bidder's organ are similar to diplotenic ovarian oocytes, surrounded by a layer of follicular cells in both cases [167]. Therefore, it is not surprising that the expression profile of Bidder's organ, although different, is more similar to developing ovaries than testes [163].

The pre-vitellogenic oocytes in Bidder's organ do not mature, but undergo a degenerative process, ending with their reabsorption by the follicle cells $[164,167,168]$. The stock of stem germ cells (for successive annual oogenetic waves) is maintained as nests of germ cells at different stages of oogenesis. Low doses of estrogens can induce vitellogenesis in the bidderian oocytes, but not their maturation [168]. Treatments with different sex-steroids and antiandrogens reveal that the germ cells of Bidder's organ have a strong commitment to the oogenetic pathway, probably related to their early entry into meiosis [169]. On the other hand, after removal of the testes by orchidectomy, Bidder's organ becomes a functional ovary and the oocytes reach vitellogenic stages and complete maturation (e.g., B. bufo [168,170], B. woodhousii [165], and Rhinella marina [167]). Thus, the testes (androgens) inhibit the complete maturation of bidderian germ cells (probably inhibiting the response to gonadotropin), but not their proliferation and the oogenetic pathway [165].

The formation of Bidder's organ may be related to localized high levels of retinoic acid in a region with early high expression levels of Raldh2 (which catalyzes the synthesis of retinoic acid) and low levels of Cyp26b1 (involved in the inactivation of retinoic acid) [171]. Increased levels of retinoic acid may be the reason for the early entry into meiosis and the advanced development observed in the bidderian germ cells, compared with those of the developing ovary [161]. 
The function of Bidder's organ is still unknown. It has been considered a vestigial structure, or a morphological strategy to produce sexual cells for the reproduction of the species [164]. The most appealing hypothesis suggests that Bidder's organ is a functional steroidogenic organ $[163,172]$ that could be involved in the control of reproductive activity [162].

\section{Genetic Control of Testicular Differentiation}

Analysis of the genes expressed sex-specifically in the developing gonads of mammals [173], birds [174], reptiles [175,176], amphibians [177], and fish [178] reveals common genes between groups. However, differences in the expression patterns are also evident in different clades, with different genes showing heterochronic shifts between species (e.g., see Figure 4 in [179] for a comparison of the temporal onset of genes with sex-specific expression between turtles and mice during testis development) [177,179-181].

According to the current view, the differentiation of the gonads as testes or ovaries is not considered to be under the control of unidirectional pathways, but regulated by mutually exclusive (antagonistic) non-hierarchical networks [182]. These regulatory networks will activate one pathway while inhibiting the other to ensure that only one gonadal phenotype is achieved and maintained in adults. The molecular networks involved in testis differentiation in amphibians are not fully understood, as they have not been uncovered to the depth of those working in mice, chicken, reptiles, or fish (for a review, see $[44,114,179]$ ). The main reason may be related to the limitations of the amphibian species used as models to study the molecular networks involved in gonadal development. X. laevis can be sexed easily, but the interpretation of the gene expression results is difficult when differences between paralogous genes cannot be considered or have not been taken into account (e.g., comparing the dmrt1 expression patterns in $[119,183,184])$. X. tropicalis, the diploid alternative to $X$. laevis, has three sex chromosomes, and the genetic sex of developing tadpoles cannot be easily established. G. rugosa is another widely studied species, although the existence of several populations with different sex chromosomes should be considered when the results are analyzed (e.g., differences in steroid sensitivity have been found between different populations [185]). Finally, regarding urodeles, $P$. waltl constitutes a well-known and widely used model. Its only limitation (and advantage from an evolutionary point of view) is that the results obtained may not be extrapolated to anurans.

Transcriptome analysis during gonadal differentiation has been performed in two anuran species (X. laevis and X. tropicalis) $[177,186,187]$, whereas the information available on urodeles (the newt Cynops orientalis) is from adult gonads [181]. In addition, orthologs of genes known to be part of the gonadal differentiation pathway in mammals (DMRT1, SOX9, FOXL2, AMH, DAX1, WNT4, SF1, etc.) are also expressed during gonadal development in amphibians and have been analyzed in a wide number of anuran and urodelan species [119,135,171,183,188-192]. In general, these genes have expression profiles similar to those observed in other vertebrates, although differences between species regarding the onset and expression patterns reveal differences between the molecular networks, even in closely related species.

Gonadal expression patterns suggest that $d m r t 1$ has an important role in the differentiation of male gonads in amphibians (X. laevis [119,183,184,188,193], G. rugosa [194], B. bombina, B. viridis, H. arborea, $R$. arvalis and $R$. temporaria [188], H. retardatus [195]). The dmrt1 gene was upregulated in differentiating amphibian testes [196-199], in the sex-reversed gonads of genetic females [194,200], and in female-to-male sex-reversed ZW gonads from G. rugosa tadpoles that were transgenic for ar and treated with low levels of testosterone [30]. On the other hand, in male-to-female sex reversal, dmrt1 is downregulated. This has been described in the urodele $H$. retardatus, when genetic males were transformed into phenotypic females by means of high temperature treatments [195]. In X. laevis, the function of $d m r t 1$ in testis differentiation is antagonized by $d m-w$. The opposed roles of $d m-w$ and $d m r t 1$ in testis differentiation are evident, as their overexpression induces ovarian and testicular development in ZZ and ZW gonads, respectively [73,74]. Furthermore, over-expression of 
the $d m$ - $w$ transgene in X. laevis ZZ gonads results in a high expression of cyp19a1 and foxl2 in developing gonads [74]. These two genes are involved in the differentiation of the ovary; both are upregulated in the gonads of female tadpoles or in the gonads of male-to female sex-reversed tadpoles [44,177,201]: cyp19a1 (aromatase) converts testosterone into estrogen, leading to feminization, whereas foxl2 can promote cyp19a1 transcription in a Xenopus cell line [202].

Dmrt1 is also required for spermatogonial stem cell maintenance in mice [203]. As in other vertebrates, in X. laevis two distinct promoters control the expression of dmrt1.L in Sertoli cells in males and in germ cells in both sexes [119]. The elimination of the transcripts derived from the germ cell-specific promoter causes a reduction in the number of germ cells in male and female gonads and results in female-to-male sex reversal in ZW tadpoles [119]. These results indicate that oocyte-produced signaling molecules could maintain the suppression of testis differentiation [204]. This has been demonstrated in zebrafish, as oocyte-produced Bmp15 maintains cyp19a1a expression and estrogen production in granulosa cells, whereas Bmp15-deficient females became fertile males during the midto late-juvenile stage [205].

Steroids play important roles in sex differentiation in amphibians. Exogenous androgens or estrogens affect sexual differentiation during critical periods of development and cause the complete or partial sex reversal of the gonads [45]. Thus, it is not strange that one of the earliest changes in gene expression (taking place before any sign of gonadal differentiation) observed in developing tadpoles of X. laevis and G. rugosa concerns two steroidogenic enzymes, cyp17a1 (a key enzyme involved in the production of male sex steroids) and cyp19a1 (which controls the androgen/estrogen ratio by catalyzing the conversion of testosterone into estradiol) [196,197].

Other steroidogenic enzymes may be involved in gonadal differentiation. For example, the activity of $5 \alpha$-reductase is higher in males than in females, leading to an increase in the conversion of testosterone into dihydrotestosterone (DHT). In this way, the ratio of DHT to estradiol could be responsible for male or female gonadal development [206].

The androgen receptor (ar) is involved in testis differentiation. In G. rugosa, the gene encoding ar is located on the sex chromosomes (Z, W, Y, and X) of this species [79]; and the W-linked ar copy has a lower level of expression than the Z-linked copy [80]. The Z-ar transgene, together with low doses of testosterone, can induce testis differentiation and the upregulation of $d m r t 1$ and cyp17a1 in transgenic $\mathrm{ZW}$ tadpoles [30], suggesting that both genes could be a possible downstream target of Z-ar in this species.

Sox9 is a key element in the testis pathway of mammals and birds, suggesting a conserved role for this gene in male differentiation [179,207]. However, sox9 may not have a major role in testicular differentiation in amphibians. In X. tropicalis, sox9 is detected in both male and female gonads after metamorphosis, indicating that this gene does not play a major role in early gonadal differentiation [189]. A similar situation was described in G. rugosa and R. marina, where sox9 is expressed in both sexes during development, whereas upregulation in the testes was observed after metamorphosis [208,209]. In X. laevis, both sox9 paralogs show higher expression in ZZ than ZW gonads during tadpole development [184], suggesting a possible role in testis differentiation. However, according to immunostaining results [184], it is also possible that these sequences are expressed in germ cells. In fact, expression of sox 9 in germ cells after metamorphosis has been described in X. tropicalis [189]. Thus, taking into account its participation in germ cell differentiation in fish [210], its role in somatic cell differentiation during testis development in birds and mammals must have been acquired later during evolution.

$A m h$, another key player in the testis-determining pathway in vertebrates, has a role in testis differentiation that is largely dependent on the clade analyzed. In mammals, Sox 9 cooperates with Sf1 to activate Amh expression during testicular development [211]. In amphibians [184,209], as in chickens [212], amh precedes sox9 expression. Upregulation of amh expression in the developing anuran testes has been described in X. tropicalis, X. laevis, and G. rugosa, among others $[184,188,213,214]$. In X. tropicalis, the Müllerian ducts begin to 
form between stages 57-66, according to [123], once the gonads have differentiated into testes or ovaries [213]. Thus, earlier expression in males could indicate a role in gonadal differentiation. In P. waltl, amh was also expressed at higher levels in the developing testes compared with the ovaries, with higher levels before and during gonadal differentiation in male gonads [191]. This profile of $a m h$ expression during the differentiation of amphibian testes could be related to its role in the control of germ cell proliferation, as described in fish [215-217]. In fact, in parabiosis experiments, in ZZ/ZW associations in P. waltl, the germ cell numbers in the ZW gonad were similar to those observed in the ZZ gonad and two-fold lower than in a control ZW gonad [218]. Similarly, mutations in the receptor of amh (amhrII) in the medaka caused the feminization of the gonads by altering proliferation at a specific stage of germ cell development $[215,217]$. This evidence suggests that $a m h$ had a primitive role in the proliferation and development of germ cells in early and adult gonads of both sexes, acquiring the function of Müllerian duct regression later during evolution [219].

Regarding the role of amh in Müllerian duct regression in amphibians, it is noteworthy that these ducts are maintained without differentiation in the male sex in urodeles $[49,104]$ despite the expression and synthesis of amh in the developing testes [191]. Analysis of the expression of $a m h r 2$ in the Müllerian ducts of the urodeles may explain its persistence, even though amh is expressed.

\section{Conclusions}

A general lack of knowledge exists about the sex-determining genes existing in amphibians. The available information on the sex chromosomes in this group predicts the existence of a wide variety of sex-determining genes. To improve our knowledge on amphibian testicular differentiation, it will be necessary to uncover more sex-determining genes in other species.

The undifferentiated amphibian gonads are organized into two domains: the cortex and the medulla. One of the first morphological signs of testis differentiation is the movement of germ cells from the cortex to the medulla (germ cells remain in the cortex in females). Among the main differences with testes in amniotes are: (1) the spermatogenesis takes place into the cyst; (2) all the germ cells that interact with one Sertoli cell in a cyst are at the same developmental stage; (3) there is a turnover of Sertoli cells in the adult due to the transient nature of the germinal epithelium. As consequence, the spermatogenic efficiency and the Sertoli supporting capacity of the testis are higher compared to amniotes.

Amphibians do not resemble fish in regard to their extreme testis plasticity, although examples of testis plasticity can be found in urodelans, in which new testis lobes develop in adult life. Furthermore, ovarian-like structures with pre-vitellogenic oocytes (Bidder's organ) persist attached to the testes in bufonid males. The testis has an inhibitory effect on the differentiation of Bidder's organ as an ovary, but no lethal effect on the germ cells.

The gene networks controlling testis differentiation in amphibians are closer to those in fish than those in birds and mammals. dmrt1, cyp19a1, foxl2, and cyp17a1 are major players in controlling the gonadal development of amphibians. Establishing relations between these and other elements will require functional analysis. Amphibians are emerging as interesting models to discover how mutually exclusive networks evolved in vertebrates to control gonadal differentiation and how new sex-determining genes are frequently added to these networks in different species.

Author Contributions: Conceptualization, M.B.; investigation, Á.S.R., A.R.-G. and M.B.; writingoriginal draft preparation, Á.S.R., A.R.-G. and M.B.; writing-review and editing, M.B.; funding acquisition, M.B. All authors have read and agreed to the published version of the manuscript.

Funding: This research was funded by the Spanish Ministerio de Ciencia, Innovación y Universidades, grant number BFU2016-78001-P (cofunded by the European Regional Development Fund), by the Junta de Andalucía (program "Ayudas a grupos de investigación" (group RNM-924)), and by the Universidad de Jaén (program Plan de Apoyo a la Investigación, Acción 1). 
Institutional Review Board Statement: Not applicable.

Informed Consent Statement: Not applicable.

Data Availability Statement: Data sharing not applicable.

Conflicts of Interest: The authors declare no conflict of interest.

\section{References}

1. AmphibiaWeb. Available online: https://amphibiaweb.org (accessed on 1 April 2021).

2. Schmid, M.; Evans, B.J.; Bogart, J.P. Polyploidy in Amphibia. Cytogenet. Genome Res. 2015, 145, 315-330. [CrossRef] [PubMed]

3. Ragghianti, M.; Bucci, S.; Marracci, S.; Casola, C.; Mancino, G.; Hotz, H.; Guex, G.-D.; Plötner, J.; Uzzell, T. Gametogenesis of intergroup hybrids of hemiclonal frogs. Genet. Res. 2007, 89, 39-45. [CrossRef] [PubMed]

4. Bogart, J.P.; Bi, K.; Fu, J.; Noble, D.W.A.; Niedzwiecki, J. Unisexual salamanders (genus Ambystoma) present a new reproductive mode for eukaryotes. Genome 2007, 50, 119-136. [CrossRef]

5. Khokha, M.K.; Krylov, V.; Reilly, M.J.; Gall, J.G.; Bhattacharya, D.; Cheung, C.Y.J.; Kaufman, S.; Lam, D.K.; Macha, J.; Ngo, C.; et al. Rapid gynogenetic mapping of Xenopus tropicalis mutations to chromosomes. Dev. Dyn. 2009, 238, 1398-1406. [CrossRef] [PubMed]

6. Smith, J.J.; Voss, S.R. Amphibian sex determination: Segregation and linkage analysis using members of the tiger salamander species complex (Ambystoma mexicanum and A. t. tigrinum). Heredity 2009, 102, 542-548. [CrossRef]

7. Stöck, M.; Lamatsch, D.K.; Steinlein, C.; Epplen, J.T.; Grosse, W.-R.; Hock, R.; Klapperstück, T.; Lampert, K.P.; Scheer, U.; Schmid, M.; et al. A bisexually reproducing all-triploid vertebrate. Nat. Genet. 2002, 30, 325-328. [CrossRef] [PubMed]

8. Levis, N.A.; Pfennig, D.W. Phenotypic plasticity, canalization, and the origins of novelty: Evidence and mechanisms from amphibians. Semin. Cell Dev. Biol. 2019, 88, 80-90. [CrossRef] [PubMed]

9. Haddad, C.F.B.; Prado, C.P.A. Reproductive modes in frogs and their unexpected diversity in the Atlantic forest of Brazil. Bioscience 2005, 55, 207-217. [CrossRef]

10. Ogielska, M. (Ed.) Reproduction of Amphibians; Science Publishers: Rawalpindi, Pakistan, 2009; ISBN 9783540773405.

11. Jeffries, D.L.; Lavanchy, G.; Sermier, R.; Sredl, M.J.; Miura, I.; Borzée, A.; Barrow, L.N.; Canestrelli, D.; Crochet, P.-A.; Dufresnes, C.; et al. A rapid rate of sex-chromosome turnover and non-random transitions in true frogs. Nat. Commun. 2018, 9, 4088. [CrossRef] [PubMed]

12. Furman, B.L.S.; Evans, B.J. Divergent Evolutionary Trajectories of Two Young, Homomorphic, and Closely Related Sex Chromosome Systems. Genome Biol. Evol. 2018, 10, 742-755. [CrossRef]

13. Cauret, C.M.S.; Gansauge, M.T.; Tupper, A.S.; Furman, B.L.S.; Knytl, M.; Song, X.Y.; Greenbaum, E.; Meyer, M.; Evans, B.J.; Wilson, M. Developmental Systems Drift and the Drivers of Sex Chromosome Evolution. Mol. Biol. Evol. 2020, 37, 799-810. [CrossRef]

14. Stöck, M.; Croll, D.; Dumas, Z.; Biollay, S.; Wang, J.; Perrin, N. A cryptic heterogametic transition revealed by sex-linked DNA markers in Palearctic green toads. J. Evol. Biol. 2011, 24, 1064-1070. [CrossRef]

15. Schmid, M.; Steinlein, C.; Feichtinger, W. Chromosome banding in Amphibia. XVII. First demonstration of multiple sex chromosomes in amphibians: Eleutherodactylus maussi (Anura, leptodactylidae). Chromosoma 1992, 101, 284-292. [CrossRef]

16. Schmid, M.; Feichtinger, W.; Steinlein, C.; Visbal García, R.; Fernández Badillo, A. Chromosome banding in Amphibia: XXVIII. Homomorphic XY sex chromosomes and a derived Y-autosome translocation in Eleutherodactylus riveroi (Anura, Leptodactylidae). Cytogenet. Genome Res. 2003, 101, 62-73. [CrossRef] [PubMed]

17. Miura, I.; Shams, F.; Lin, S.; Cioffi, M.D.B.; Liehr, T.; Al-rikabi, A.; Kuwana, C.; Srikulnath, K.; Higaki, Y.; Ezaz, T. Evolution of a Multiple Sex-Chromosome System by Three-Sequential Translocations among Potential Sex-Chromosomes in the Taiwanese Frog Odorrana swinhoana. Cells 2021, 10, 661. [CrossRef]

18. Gazoni, T.; Haddad, C.F.B.; Narimatsu, H.; Cabral-De-Mello, D.C.; Lyra, M.L.; Parise-Maltempi, P.P. More sex chromosomes than autosomes in the Amazonian frog Leptodactylus pentadactylus. Chromosoma 2018, 1-10. [CrossRef] [PubMed]

19. Green, D.M. Cytogenetics of the endemic New Zealand frog, Leiopelma hochstetteri: Extraordinary supernumerary chromosome variation and a unique sex-chromosome system. Chromosoma 1988, 97, 55-70. [CrossRef]

20. Hillis, D.M.; Green, D.M. Evolutionary changes of heterogametic sex in the phylogenetic history of amphibians. J. Evol. Biol. 1990, 3, 49-64. [CrossRef]

21. Schmid, M.; Steinlein, C.; Bogart, J.P.; Feichtinger, W.; León, P.; La Marca, E.; Díaz, L.M.; Sanz, A.; Chen, S.H.; Hedges, S.B. The chromosomes of terraranan frogs: Insights into vertebrate cytogenetics. Cytogenet. Genome Res. 2010, 130-131, 1-568. [CrossRef] [PubMed]

22. Schmid, M.; Steinlein, C. Sex chromosomes, sex-linked genes, and sex determination in the vertebrate class amphibia. In Genes and Mechanisms in Vertebrate Sex Determination; Scherer, G., Schmid, M., Eds.; Birkhäuser Verlag: Basel, Switzerland, $2001 ;$ pp. 143-176.

23. Ashman, T.-L.; Bachtrog, D.; Blackmon, H.; Goldberg, E.E.; Hahn, M.W.; Kirkpatrick, M.; Kitano, J.; Mank, J.E.; Mayrose, I.; Ming, R.; et al. Tree of sex: A database of sexual systems. Sci. Data 2014, 1, 1-8. [CrossRef]

24. Dournon, C.; Houillon, C. Démonstration génétique de l'inversion fonctionnelle du phénotype sexuel femelle sous l'action de la température d'élevage chez l'Amphibien Urodèle: Pleurodeles waltlii Michah. Reprod. Nutr. Dévelop. 1984, 24, 361-378. [CrossRef]

25. Chang, C.Y.; Witschi, E. Genic Control and Hormonal Reversal of Sex Differentiation in Xenopus. Proc. Soc. Exp. Bioi. Med. 1956, 93, 140-144. [CrossRef] [PubMed] 
26. Mikamo, K.; Witschi, E. Masculinization and Breeding of the WW Xenopus. Exp. XX 1964, 622-623. [CrossRef] [PubMed]

27. Miura, I.; Ohtani, H.; Fujitani, T. Unusual sex-ratios and developmental mortality in the rice frog Fejervarya kawamurai. Chromosom. Sci. 2015, 18, 53-57. [CrossRef]

28. Lambert, M.R.; Skelly, D.K.; Ezaz, T. Sex-linked markers in the North American green frog (Rana clamitans) developed using DArTseq provide early insight into sex chromosome evolution. BMC Genom. 2016, 17, 844. [CrossRef]

29. Furman, B.L.S.; Evans, B.J. Sequential Turnovers of Sex Chromosomes in African Clawed Frogs (Xenopus) Suggest Some Genomic Regions are Good at Sex Determination. G3 Genes Genomes Genet. 2016, 6, 3625-3633.

30. Fujii, J.; Kodama, M.; Oike, A.; Matsuo, Y.; Min, M.-S.; Hasebe, T.; Ishizuya-Oka, A.; Kawakami, K.; Nakamura, M. Involvement of androgen receptor in sex determination in an amphibian species. PLoS ONE 2014, 9, e93655. [CrossRef]

31. Uno, Y.; Nishida, C.; Takagi, C.; Igawa, T.; Ueno, N.; Sumida, M.; Matsuda, Y. Extraordinary Diversity in the Origins of Sex Chromosomes in Anurans Inferred from Comparative Gene Mapping. Cytogenet. Genome Res. 2015, 145, 218-229. [CrossRef] [PubMed]

32. Phillips, B.C.; Rodrigues, N.; Jansen van Rensburg, A.; Perrin, N. Phylogeography, more than elevation, accounts for sex chromosome differentiation in Swiss populations of the common frog (Rana temporaria). Evolution 2020, 74, 644-654. [CrossRef]

33. Rodrigues, N.; Merilä, J.; Patrelle, C.; Perrin, N. Geographic variation in sex-chromosome differentiation in the common frog (Rana temporaria). Mol. Ecol. 2014, 23, 3409-3418. [CrossRef] [PubMed]

34. Miura, I. Sex Determination and Sex Chromosomes in Amphibia. Sex. Dev. 2017, 8526, 298-306. [CrossRef] [PubMed]

35. Miura, I. An evolutionary witness: The frog Rana rugosa underwent change of heterogametic sex from XY male to ZW female. Sex. Dev. 2008, 1, 323-331. [CrossRef]

36. Roco, Á.S.; Olmstead, A.W.; Degitz, S.J.; Amano, T.; Zimmerman, L.B.; Bullejos, M. Coexistence of Y, W, and Z sex chromosomes in Xenopus tropicalis. Proc. Natl. Acad. Sci. USA 2015, 112, E4752-E4761. [CrossRef]

37. Oike, A.; Watanabe, K.; Min, M.-S.; Tojo, K.; Kumagai, M.; Kimoto, Y.; Yamashiro, T.; Matsuo, T.; Kodama, M.; Nakamura, Y.; et al. Origin of sex chromosomes in six groups of Rana rugosa frogs inferred from a sex-linked DNA marker. J. Exp. Zool. Part A Ecol. Integr. Physiol. 2017, 327, 444-452. [CrossRef] [PubMed]

38. Ogata, M.; Lee, J.Y.; Kim, S.; Ohtani, H.; Sekiya, K.; Igarashi, T.; Hasegawa, Y.; Ichikawa, Y.; Miura, I. The prototype of sex chromosomes found in Korean populations of Rana rugosa. Cytogenet. Genome Res. 2002, 99, 185-193. [CrossRef] [PubMed]

39. Ogata, M.; Lambert, M.; Ezaz, T.; Miura, I. Reconstruction of female heterogamety from admixture of XX-XY and ZZ-ZW sex-chromosome systems within a frog species. Mol. Ecol. 2018, 1-12. [CrossRef] [PubMed]

40. Nishioka, M.; Hanada, H.; Miura, I.; Ryuzaki, M. Four kinds of sex chromosomes in Rana rugosa. Sci. Rep. Lab. Amphib. Biol. Hiroshima Univ. 1994, 13, 1-34.

41. Uno, Y.; Nishida, C.; Yoshimoto, S.; Ito, M.; Oshima, Y.; Yokoyama, S.; Nakamura, M.; Matsuda, Y. Diversity in the origins of sex chromosomes in anurans inferred from comparative mapping of sexual differentiation genes for three species of the Raninae and Xenopodinae. Chromosom. Res. 2008, 16, 999-1011. [CrossRef]

42. Miura, I.; Ohtani, H.; Ogata, M. Independent degeneration of W and Y sex chromosomes in frog Rana rugosa. Chromosom. Res. 2012, 20, 47-55. [CrossRef]

43. Furman, B.L.S.; Cauret, C.M.S.; Knytl, M.; Song, X.Y.; Premachandra, T.; Ofori-Boateng, C.; Jordan, D.C.; Horb, M.E.; Evans, B.J. A frog with three sex chromosomes that co-mingle together in nature: Xenopus tropicalis has a degenerate $\mathrm{W}$ and a $\mathrm{Y}$ that evolved from a Z chromosome. PLoS Genet. 2020, 16, e1009121. [CrossRef]

44. Miura, I.; Takase, M.; Nakamura, M. Sex determination and differentiation in amphibians. In Reproductive and Developmental Strategies; Kobayashi, K., Kitano, T., Iwao, Y., Kondo, M., Eds.; Springer: Tokyo, Japan, 2018; pp. 349-366. ISBN 9784431566090.

45. Hayes, T.B. Sex determination and primary sex differentiation in amphibians: Genetic and developmental mechanisms. J. Exp. Zool. 1998, 281, 373-399. [CrossRef]

46. Nakamura, M. The mechanism of sex determination in vertebrates-are sex steroids the key-factor? J. Exp. Zool. A Ecol. Genet. Physiol. 2010, 313, 381-398. [CrossRef]

47. Nakamura, M. Is a sex-determining gene(s) necessary for sex-determination in amphibians? Steroid hormones may be the key factor. Sex. Dev. 2013, 7, 104-114. [CrossRef]

48. Eggert, C. Sex determination: The amphibian models. Reprod. Nutr. Dev. 2004, 44, 539-549. [CrossRef]

49. Flament, S. Sex Reversal in Amphibians. Sex. Dev. 2016, 10, 267-278. [CrossRef]

50. Wallace, H.; Badawy, G.M.I.; Wallace, B.M.N. Amphibian sex determination and sex reversal. Cell. Mol. Life Sci. 1999, 55, 901-909. [CrossRef]

51. Dournon, C.; Houillon, C.; Pieau, C. Temperature sex-reversal in amphibians and reptiles. Int. J. Dev. Biol. 1990, 34, 81-92. [PubMed]

52. Li, X.-H.; Zhao, W.-G.; Guo, Y.-M.; Xue, J.-H. Development of Sexual Gland and Influence of Temperature on Sexual Differentiation in Rana chensinensis. Zool. Res. 2001, 22, 351-356.

53. Mei, Y.; Zheng, R.; Zheng, S.; Yan, H.; Liu, Z.; Zhang, Q.; Wang, Z.; Hong, Y. Gonad differentiation and the effects of temperature on sex determination in Quasipaa spinosa. Acta Ecol. Sin. 2018, 38, 4809-4816. [CrossRef]

54. Sang, L.; Yong-Long, Y.; Jun, L.D. Gonad differentiation and the effects of temperature on sex determination in the rice frog Rana limnocharis. Acta Ecol. Sin. 2008, 54, 271-281. 
55. Kobel, H.R. Allopolyploid speciation. In The Biology of Xenopus; Kobel, H.R., Tinsley, R.C., Eds.; Clarendon Press: Wotton-underEdge, UK, 1996; pp. 391-401.

56. Sakata, N.; Tamori, Y.; Wakahara, M. P450 aromatase expression in the temperature-sensitive sexual differentiation of salamander (Hynobius retardatus) gonads. Int. J. Dev. Biol. 2005, 49, 417-425. [CrossRef]

57. Dournon, C.; Guillet, F.; Boucher, D.; Lacroix, J.C. Cytogenetic and genetic evidence of male sexual inversion by heat treatment in the newt Pleurodeles poireti. Chromosoma 1984, 90, 261-264. [CrossRef]

58. Wallace, H.; Wallace, B.M.N. Sex reversal of the newt Triturus cristatus reared at extreme temperatures. Int. J. Dev. Biol. 2000, 44, 807-810. [CrossRef]

59. Ruiz-García, A.; Roco, Á.S.; Bullejos, M. Sex-differentiation in amphibians: Effect of temperature and its influence on sex reversal. Sex. Dev. 2021, in press. [CrossRef]

60. Lambert, M.R.; Tran, T.; Kilian, A.; Ezaz, T.; Skelly, D.K. Molecular evidence for sex reversal in wild populations of green frogs (Rana clamitans). PeerJ 2019, 2019, 1-21. [CrossRef]

61. Alho, J.S.; Matsuba, C.; Merilä, J. Sex reversal and primary sex ratios in the common frog (Rana temporaria). Mol. Ecol. 2010, 19, 1763-1773. [CrossRef]

62. Schartl, M. Sex chromosome evolution in non-mammalian vertebrates. Curr. Opin. Genet. Dev. 2004, 14, 634-641. [CrossRef]

63. Pan, Q.; Anderson, J.; Bertho, S.; Herpin, A.; Wilson, C.; Postlethwait, J.H.; Schartl, M.; Guiguen, Y. Vertebrate sex-determining genes play musical chairs. Comptes Rendus Biol. 2016, 339, 258-262. [CrossRef] [PubMed]

64. Herpin, A.; Schartl, M. Plasticity of gene-regulatory networks controlling sex determination: Of masters, slaves, usual suspects, newcomers, and usurpators. EMBO Rep. 2015, 16, 1-15. [CrossRef] [PubMed]

65. Ito, M.; Mawaribuchi, S. Molecular Evolution of Genes Involved in Vertebrate Sex Determination. eLS 2013, 1-7. [CrossRef]

66. Mawaribuchi, S.; Yoshimoto, S.; Ohashi, S.; Takamatsu, N.; Ito, M. Molecular evolution of vertebrate sex-determining genes. Chromosom. Res. 2012, 20, 139-151. [CrossRef]

67. Yoshimoto, S.; Okada, E.; Umemoto, H.; Tamura, K.; Uno, Y.; Nishida-umehara, C.; Matsuda, Y.; Takamatsu, N.; Shiba, T.; Ito, M. A W-linked DM-domain gene, DM-W, participates in primary ovary development in Xenopus laevis. Proc. Natl. Acad. Sci. USA 2008, 105, 2469-2474. [CrossRef]

68. Mikamo, K.; Witschi, E. The mitotic chromosomes in Xenopus laevis (Daudin): Normal, sex reversed and female WW. Cytogenetics 1966, 5, 1-19. [CrossRef] [PubMed]

69. Tymowska, J. Polyploidy and Cytogenetic Variation in Frogs of the Genus Xenopus. In Amphibian Cytogenetics and Evolution; Green, D.M., Sessions, S.K., Eds.; Elsevier: Amsterdam, The Netherlands, 1991; pp. 259-297.

70. Session, A.M.; Uno, Y.; Kwon, T.; Chapman, J.A.; Toyoda, A.; Takahashi, S.; Fukui, A.; Hikosaka, A.; Suzuki, A.; Kondo, M.; et al. Genome evolution in the allotetraploid frog Xenopus laevis. Nature 2016, 538, 1-15. [CrossRef] [PubMed]

71. Mawaribuchi, S.; Takahashi, S.; Wada, M.; Uno, Y.; Matsuda, Y.; Kondo, M.; Fukui, A.; Takamatsu, N.; Taira, M.; Ito, M. Sex chromosome differentiation and the W- and Z-specific loci in Xenopus laevis. Dev. Biol. 2017, 426, 393-400. [CrossRef] [PubMed]

72. Bewick, A.J.; Anderson, D.W.; Evans, B.J. Evolution of the closely related, sex-related genes DM-W and DMRT1 in African clawed frogs (Xenopus). Evolution 2011, 65, 698-712. [CrossRef]

73. Yoshimoto, S.; Ikeda, N.; Izutsu, Y.; Shiba, T.; Takamatsu, N.; Ito, M. Opposite roles of DMRT1 and its W-linked paralogue, DM-W, in sexual dimorphism of Xenopus laevis: Implications of a ZZ/ZW-type sex-determining system. Development 2010, 137, 2519-2526. [CrossRef]

74. Okada, E.; Yoshimoto, S.; Ikeda, N.; Kanda, H.; Tamura, K.; Shiba, T.; Takamatsu, N.; Ito, M. Xenopus W-linked DM-W induces Foxl2 and Cyp19 expression during ovary formation. Sex. Dev. 2009, 3, 38-42. [CrossRef] [PubMed]

75. Kobel, H.R.; Pasquier, L.D.; Tinsley, R.C. Natural hybridization and gene introgression between Xenopus gilli and Xenopus laevis laevis (Anura: Pipidae). J. Zool. 1981, 194, 317-322. [CrossRef]

76. Picker, M.D. Hybridization and Habitat Selection in Xenopus gilli and Xenopus laevis in the South-Western Cape Province. Copeia 1985, 1985, 574-580. [CrossRef]

77. Picker, M.D.; Harrison, J.; Wallace, D. Natural hybridization between Xenopus laevis laevis and X. gilli in the south-western Cape province, South Africa. In The Biology of Xenopus; Kobel, H.R., Tinsley, R.R., Eds.; Oxford University Press: Oxford, UK, 1996; pp. $61-70$.

78. Kobel, H.R.; Pasquier, L. Du Genetics of polyploid Xenopus. Trends Genet. 1986, 2, 310-315. [CrossRef]

79. Uno, Y.; Nishida, C.; Oshima, Y.; Yokoyama, S.; Miura, I.; Matsuda, Y.; Nakamura, M. Comparative chromosome mapping of sex-linked genes and identification of sex chromosomal rearrangements in the Japanese wrinkled frog (Rana rugosa, Ranidae) with ZW and XY sex chromosome systems. Chromosom. Res. 2008, 16, 637-647. [CrossRef] [PubMed]

80. Yokoyama, S.; Oshima, Y.; Tokita, J.; Suda, M.; Shinozuka, T.; Nakamura, M. Androgen receptor of the frog Rana rugosa: Molecular cloning and its characterization. J. Exp. Zool. A Ecol. Genet. Physiol. 2009, 311, 796-812. [CrossRef] [PubMed]

81. Oike, A.; Kodama, M.; Yasumasu, S.; Yamamoto, T.; Nakamura, Y.; Ito, E.; Nakamura, M. Participation of androgen and its receptor in sex determination of an amphibian species. PLoS ONE 2017, 12, 1-16. [CrossRef]

82. Nishioka, M.; Hanada, H. Sex of Reciprocal Hybrids between the Hamakita (XX-XY Type) Population and the Murakami (ZW-ZZ Type) Population of Rana rugosa. Sci. Rep. Lab. Amphib. Biol. Hiroshima Univ. 1994, 13, 35-50.

83. Schmid, M.; Ohta, S.; Steinlein, C.; Guttenbach, M. Chromosome banding in Amphibia XIX. Primitive ZW/ZZ sex chromosomes in Buergeria buergeri (Anura, Rhacophoridae). Cytogenet. Cell Genet. 1993, 62, 238-246. [CrossRef] [PubMed] 
84. Ohta, S.; Sumida, M.; Nishioka, M. Sex-determining mechanism in Buergeria buergeri (Anura, Rhacophoridae). III. Does the ZZW triploid frog become female or male? J. Exp. Zool. 1999, 283, 295-306. [CrossRef]

85. Perrin, N. Random sex determination: When developmental noise tips the sex balance. BioEssays 2016, 1-9. [CrossRef]

86. Witschi, E. Studies on sex differentiation and sex determination in amphibians. III. Rudimentary hermaphroditism and $\mathrm{Y}$ chromosome in Rana temporaria. J. Exp. Zool. 1929, 54, 157-222. [CrossRef]

87. Ogielska, M.; Kotusz, A. Pattern and Rate of Ovary Differentiation with Reference to Somatic Development in Anuran Amphibians. J. Morphol. 2004, 259, 41-54. [CrossRef]

88. Goldberg, J. Gonadal differentiation and development in the snouted treefrog, Scinax fuscovarius (Amphibia, Anura, Hylidae). J. Herpetol. 2015, 49, 468-478. [CrossRef]

89. Gramapurohit, N.P.; Shanbhag, B.A.; Saidapur, S.K. Pattern of gonadal sex differentiation, development, and onset of steroidogenesis in the frog, Rana curtipes. Gen. Comp. Endocrinol. 2000, 119, 256-264. [CrossRef] [PubMed]

90. Witschi, E. Studies on sex differentiation and sex determination in amphibians. IV. The geographical distribution of the sex races of the European grass frog (Rana temporaria, L.). A contribution to the problem of the evolution of sex. J. Exp. Zool. 1930, 56, 149-165. [CrossRef]

91. Falconi, R.; Dalpiaz, D.; Zaccanti, F. Ultrastructural aspects of gonadal morphogenesis in Bufo bufo (Amphibia Anura) 1. Sex differentiation. J. Exp. Zool. A. Comp. Exp. Biol. 2004, 301, 378-388. [CrossRef] [PubMed]

92. Ogielska, M. The Undifferentiated Amphibian Gonad. In Reproduction of Amphibians; Ogielska, M., Ed.; Science Publishers: Rawalpindi, Pakistan, 2009; pp. 1-33.

93. Tanimura, A.; Iwasawa, H. Origin of somatic cells and histogenesis in the primordial gonad of the Japanese tree frog Rhacophorus arboreus. Anat. Embryol. 1989, 180, 165-173. [CrossRef]

94. Falconi, R.; Petrini, S.; Quaglia, A.; Zaccanti, F. Fine structure of undifferentiated gonads in Rana dalmatina tadpoles. Ital. J. Zool. 2001, 68, 15-21. [CrossRef]

95. Takahashi, H. Juvenile Hermaphroditism in the Zebrafish, Brachydanio rerio. Bull. Fac. Fish. Hokkaido Univ. 1977, $28,57-65$.

96. Mazzoni, T.S.; Grier, H.J.; Quagio-Grassiotto, I. The Basement Membrane and the Sex Establishment in the Juvenile Hermaphroditism During Gonadal Differentiation of the Gymnocorymbus ternetzi (Teleostei: Characiformes: Characidae). Anat. Rec. 2015, 298, 1984-2010. [CrossRef]

97. Uchida, D.; Yamashita, M.; Kitano, T.; Iguchi, T. Oocyte apoptosis during the transition from ovary-like tissue to testes during sex differentiation of juvenile zebrafish. J. Exp. Biol. 2002, 205, 711-718. [PubMed]

98. Hsu, C.W.; Pan, Y.J.; Wang, Y.W.; Tong, S.K.; Chung, B. Changes in the morphology and gene expression of developing zebrafish gonads. Gen. Comp. Endocrinol. 2018, 265, 154-159. [CrossRef]

99. Uchida, D.; Yamashita, M.; Kitano, T.; Iguchi, T. An aromatase inhibitor or high water temperature induce oocyte apoptosis and depletion of $\mathrm{P} 450$ aromatase activity in the gonads of genetic female zebrafish during sex-reversal. Comp. Biochem. Physiol. A Mol. Integr. Physiol. 2004, 137, 11-20. [CrossRef]

100. Johnson, A.D.; Drum, M.; Bachvarova, R.F.; Masi, T.; White, M.E.; Crother, B.I. Evolution of predetermined germ cells in vertebrate embryos: Implications for macroevolution. Evol. Dev. 2003, 5, 414-431. [CrossRef]

101. Flament, S.A.; Chardard, D.; Chesnel, A.; Dumond, H.G.A. Sex Determination and Sexual Differentiation in Amphibians. Horm. Reprod. Vertebr. 2011, 2, 1-19. [CrossRef]

102. Houston, D.W.; King, M. Lou Germ plasm and molecular determinants of germ cell fate. Curr. Top. Dev. Biol. 2000, 50, 155-181. [CrossRef]

103. Wakahara, M. Primordial germ cell development: Is the urodele pattern closer to mammals than to anurans? Int. J. Dev. Biol. 1996, 40, 653-659.

104. Dumond, H.; Kuntz, S.; Chesnel, A.; Ko, C.; Wallacides, A.; Chardard, D.; Flament, S. Sexual development of the urodele amphibian Pleurodeles waltl. Sex. Dev. 2008, 2, 104-114. [CrossRef]

105. Anjubault, E.; Exbrayat, J. Development of Gonads. In Reproductive Biology and Phylogeny of Gymnophiona (Caecilians); Exbrayat, J.-M., Ed.; Science Publishers: Rawalpindi, Pakistan, 2006; Volume 9, pp. 291-302.

106. Whittle, C.A.; Extavour, C.G. Causes and evolutionary consequences of primordial germ-cell specification mode in metazoans. Proc. Natl. Acad. Sci. USA 2017, 114, 5784-5791. [CrossRef]

107. Lopez, K. Sex differentiation and early gonadal development in Bombina orientalis (Anura: Discoglossidae). J. Morphol. 1989, 199, 299-311. [CrossRef]

108. Wylie, C.C.; Heasman, J. The formation of the gonadal ridge in Xenopus laevis I. A light and transmission electron microscope study. J. Embryol. Exp. Morphol. 1976, 35, 125-138. [PubMed]

109. Piprek, R.P.; Pecio, A.; Szymura, J.M. Differentiation and development of gonads in the yellow-bellied toad, Bombina variegata L., 1758 (Amphibia: Anura: Bombinatoridae). Zoolog. Sci. 2010, 27, 47-55. [CrossRef]

110. Piprek, R.P.; Pecio, A.; Kubiak, J.Z.; Szymura, J.M. Differential effects of busulfan on gonadal development in five divergent anuran species. Repod. Toxicol. 2012, 34, 393-401. [CrossRef] [PubMed]

111. Wylie, C.C.; Bancroft, M.; Heasman, J. The formation of the gonadal ridge in Xenopus laevis. II. A scanning electron microscope study. J. Embryol. Exp. Morphol. 1976, 35, 139-148. [PubMed]

112. Roco, Á.S.; Ruiz García, A.; Bullejos, M. Interaction between sex-determining genes from two species: Clues from Xenopus hybrids. Philos. Trans. B 2021, in press. [CrossRef] 
113. Al-Asaad, I.; Dumond, H.; Chardard, D.; Chesnel, A.; Flament, S. Busulfan-mediated germ cell depletion does not alter gonad differentiation in the urodele amphibian Pleurodeles waltl. Sex. Dev. 2012, 6, 188-200. [CrossRef] [PubMed]

114. DeFalco, T.; Capel, B. Gonad morphogenesis in vertebrates: Divergent means to a convergent end. Annu. Rev. Cell Dev. Biol. 2009, 25, 457-482. [CrossRef] [PubMed]

115. Tanimura, A.; Iwasawa, H. Ultrastructural Observations on the Origin and Differentiation of Somatic Cells during Gonadal Development in the Frog Rana nigromaculata. Dev. Growth Differ. 1988, 30, 681-691. [CrossRef]

116. Mendoza-Cruz, E.; Moreno-Mendoza, N.; Zambrano, L.; Villagrán-SantaCruz, M. Development and gonadal sex differentiation in the neotenic urodele: Ambystoma mexicanum. Zoomorphology 2017, 136, 497-509. [CrossRef]

117. Piprek, R.P.; Kloc, M.; Tassan, J.-P.; Kubiak, J.Z. Development of Xenopus laevis bipotential gonads into testis or ovary is driven by sex-specific cell-cell interactions, proliferation rate, cell migration and deposition of extracellular matrix. Dev. Biol. 2017, 432, 298-310. [CrossRef]

118. Haczkiewicz, K.; Ogielska, M. Gonadal sex differentiation in frogs: How testes become shorter than ovaries. Zoolog. Sci. 2013, 30, 125-134. [CrossRef]

119. Mawaribuchi, S.; Musashijima, M.; Wada, M.; Izutsu, Y.; Kurakata, E.; Park, M.K.; Takamatsu, N.; Ito, M. Molecular evolution of two distinct dmrt1 promoters for germ and somatic cells in vertebrate gonads. Mol. Biol. Evol. 2017, 34, 724-733. [CrossRef]

120. Tanimura, A.; Iwasawa, H. Proliferative activity of somatic cells during gonadal development in the Japanese pond frog, Rana nigromaculata. J. Exp. Zool. 1991, 259, 365-370. [CrossRef]

121. Merchant-Larios, H.; Villalpando, I. Ultrastructural events during early gonadal development in Rana pipiens and Xenopus laevis. Anat. Rec. 1981, 199, 349-360. [CrossRef]

122. Witschi, E. Studies on sex differentiation and sex determination in amphibians. I. Development and sexual differentiation of the gonads of Rana sylvatica. J. Exp. Zool. 1929, 52, 235-265. [CrossRef]

123. Nieuwkoop, P.D.; Faber, J. Normal Table of Xenopus Laevis (Daudin): A Systematical and Chronological Survey of the Development from the Fertilized Egg Till the End of Metamorphosis; Garland Publishing, Inc.: New York, NY, USA, 1994.

124. Schmahl, J.; Eicher, E.M.; Washburn, L.L.; Capel, B. Sry induces cell proliferation in the mouse gonad. Development 2000, $127,65-73$.

125. Smith, C.A.; Joss, J.M.P. Sertoli cell differentiation and gonadogenesis in Alligator mississippiensis. J. Exp. Zool. 1994, 270, 57-70. [CrossRef]

126. Yao, H.H.-C.; DiNapoli, L.; Capel, B. Cellular mechanisms of sex determination in the red-eared slider turtle, Trachemys scripta. Mech. Dev. 2004, 121, 1393-1401. [CrossRef] [PubMed]

127. Schmahl, J.; Yao, H.H.; Pierucci-Alves, F.; Capel, B. Colocalization of WT1 and cell proliferation reveals conserved mechanisms in temperature-dependent sex determination. Genesis 2003, 35, 193-201. [CrossRef] [PubMed]

128. Saotome, K.; Isomura, T.; Seki, T.; Nakamura, Y.; Nakamura, M. Structural changes in gonadal basement membranes during sex differentiation in the frog Rana rugosa. J. Exp. Zool. A Ecol. Genet. Physiol. 2010, 313, 369-380. [CrossRef] [PubMed]

129. Dournon, C.; Durand, D.; Demassieux, C.; Lesimple, M. Differential germ cell proliferation in the salamander Pleurodeles waltl: Controls by sexual genotype and by thermal epigenetic factor before differentiation of sexual phenotype of gonads. Int. J. Dev. Biol. 1990, 34, 365-375. [CrossRef]

130. Tilmann, C.; Capel, B. Mesonephric cell migration induces testis cord formation and Sertoli cell differentiation in the mammalian gonad. Development 1999, 126, 2883-2890.

131. Combes, A.N.; Wilhelm, D.; Davidson, T.; Dejana, E.; Harley, V.R.; Sinclair, A.; Koopman, P.A. Endothelial cell migration directs testis cord formation. Dev. Biol. 2009, 326, 112-120. [CrossRef]

132. Moreno-Mendoza, N.; Harley, V.R.; Merchant-Larios, H. Temperature regulates SOX9 expression in cultured gonads of Lepidochelys olivacea, a species with temperature sex determination. Dev. Biol. 2001, 229, 319-326. [CrossRef]

133. Smith, C.A.; McClive, P.J.; Hudson, Q.; Sinclair, A.H. Male-specific cell migration into the developing gonad is a conserved process involving PDGF signalling. Dev. Biol. 2005, 284, 337-350. [CrossRef]

134. Smith, C.A.; Sinclair, A.H. Sex determination: Insights from the chicken. BioEssays 2004, 26, 120-132. [CrossRef]

135. Wallacides, A.; Chesnel, A.; Chardard, D.; Flament, S.; Dumond, H. Evidence for a conserved role of retinoic acid in urodele amphibian meiosis onset. Dev. Dyn. 2009, 238, 1389-1398. [CrossRef] [PubMed]

136. Goldberg, J.; Barrasso, D.A.; Agostini, M.G.; Quinzio, S. Vocal sac development and accelerated sexual maturity in the lesser swimming frog, Pseudis minuta (Anura, Hylidae). Zoology 2016, 119, 489-499. [CrossRef] [PubMed]

137. Downie, J.R.; Sams, K.; Walsh, P.T. The paradoxical frog Pseudis paradoxa: Larval anatomical characteristics, including gonadal maturation. Herpetol. J. 2009, 19, 1-10.

138. Griswold, M.D. The central role of Sertoli cells in spermatogenesis. Semin. Cell Dev. Biol. 1998, 9, 411-416. [CrossRef]

139. Li, L.Y.; Seddon, A.P.; Meister, A.; Risley, M.S. Spermatogenic cell-somatic cell interactions are required for maintenance of spermatogenic cell glutathione. Biol. Reprod. 1989, 40, 317-331. [CrossRef]

140. Bouma, J.; Harbor, B. Sertoli Cell Biology in Fishes and Amphibians. In Sertoli Cell Biology; Elsevier: Amsterdam, The Netherlands, 2005; pp. 71-79.

141. França, L.R.; Hess, R.A.; Dufour, J.M.; Hofmann, M.C.; Griswold, M.D. The Sertoli cell: One hundred fifty years of beauty and plasticity. Andrology 2016, 4, 189-212. [CrossRef] 
142. Castañeda Cortés, D.C.; Langlois, V.S.; Fernandino, J.I. Crossover of the hypothalamic pituitary-adrenal/interrenal, -thyroid, and -gonadal axes in testicular development. Front. Endocrinol. 2014, 5, 1-11. [CrossRef]

143. Rozenblut-Kościsty, B.; Piprek, R.P.; Pecio, A.; Bartmańska, J.; Szymura, J.M.; Ogielska, M. The structure of spermatogenic cysts and number of Sertoli cells in the testes of Bombina bombina and Bombina variegata (Bombinatoridae, Anura, Amphibia). Zoomorphology 2017, 136, 483-495. [CrossRef]

144. Haczkiewicz, K.; Rozenblut-Kościsty, B.; Ogielska, M. Prespermatogenesis and early spermatogenesis in frogs. Zoology 2017, 122, 63-79. [CrossRef] [PubMed]

145. Holstein, A.-F.; Schulze, W.; Davidoff, M. Understanding spermatogenesis is a prerequisite for treatment. Reprod. Biol. Endocrinol. 2003, 1, 1-16. [CrossRef] [PubMed]

146. Culty, M. Gonocytes, from the fifties to the present: Is there a reason to change the name? Biol. Reprod. 2013, 89, 1-6. [CrossRef] [PubMed]

147. Akat, E. Characterization of testicular histology and spermatogenesis in the Levantine frog, Pelophylax bedriagae (Amphibia: Anura: Ranidae). Ann. Limnol. 2020, 56. [CrossRef]

148. Ogielska, M.; Bartmańska, J. Development of testes and differentiation of germ cells in water frogs of the Rana esculenta-Complex (Amphibia, Anura). Amphib. Reptil. 1999, 20, 251-263. [CrossRef]

149. Schindelmeiser, J.; Greven, H.; Bergmann, M. The Immature Part of the Testis in Salamandra salamandra (L.) (Amphibia, Urodela). Arch. Histol. Jpn. 1983, 46, 159-172. [CrossRef] [PubMed]

150. Báo, S.N.; Dalton, G.C.; de Oliveira, S.F. Spermiogenesis in Odontophrynus cultripes (Amphibia, Anura, Leptodactylidae): Ultrastructural and cytochemical studies of proteins using E-PTA. J. Morphol. 1991, 207, 303-314. [CrossRef]

151. Uribe, M.C.; Gracia-Fernández, S. Sequence of Germ Cells Differentiation during Spermiogenesis of the Amphibian Urodele Ambystoma dumerilii. Spermatozoa Facts Perspect. 2018. [CrossRef]

152. Pierantoni, R.; Cobellis, G.; Meccariello, R.; Palmiero, C.; Fienga, G.; Minucci, S.; Fasano, S. The amphibian testis as model to study germ cell progression during spermatogenesis. Comp. Biochem. Physiol. B Biochem. Mol. Biol. 2002, 132, 131-139. [CrossRef]

153. Pudney, J. Spermatogenesis in nonmammalian vertebrates. Microsc. Res. Tech. 1995, 32, 459-497. [CrossRef]

154. Figueiredo, A.F.A.; França, L.R.; Hess, R.A.; Costa, G.M.J. Sertoli cells are capable of proliferation into adulthood in the transition region between the seminiferous tubules and the rete testis in Wistar rats. Cell Cycle 2016, 15, 2486-2496. [CrossRef]

155. França, L.R.; Nóbrega, R.H.; Morais, R.D.V.S.; De Castro Assis, L.H.; Schulz, R.W. Sertoli cell structure and function in anamniote vertebrates. In Sertoli Cell Biology; Griswold, M.D., Ed.; Elsevier Inc.: Amsterdam, The Netherlands, 2015 ; pp. 385-407. ISBN 9780124170476.

156. Matta, S.L.P.; Vilela, D.A.R.; Godinho, H.P.; França, L.R. The goitrogen 6-n-propyl-2-thiouracil (PTU) given during testis development increases Sertoli and germ cell numbers per cyst in fish: The tilapia (Oreochromis niloticus) model. Endocrinology 2002, 143, 970-978. [CrossRef]

157. Vilela, D.A.R.; Silva, S.G.B.; Peixoto, M.T.D.; Godinho, H.P.; França, L.R. Spermatogenesis in teleost: Insights from the Nile tilapia (Oreochromis niloticus) model. Fish Physiol. Biochem. 2003, 28, 187-190. [CrossRef]

158. Schulz, R.W.; Menting, S.; Bogerd, J.; França, L.R.; Vilela, D.A.R.; Godinho, H.P. Sertoli cell proliferation in the adult testisEvidence from two fish species belonging to different orders. Biol. Reprod. 2005, 73, 891-898. [CrossRef] [PubMed]

159. Leal, M.C.; Cardoso, E.R.; Nóbrega, R.H.; Batlouni, S.R.; Bogerd, J.; França, L.R.; Schulz, R.W. Histological and stereological evaluation of zebrafish (Danio rerio) spermatogenesis with an emphasis on spermatogonial generations. Biol. Reprod. 2009, 81, 177-187. [CrossRef] [PubMed]

160. Flament, S.; Dumond, H.; Chardard, D.; Chesnel, A. Lifelong testicular differentiation in Pleurodeles waltl (Amphibia, Caudata). Reprod. Biol. Endocrinol. 2009, 7, 1-12. [CrossRef]

161. Falconi, R.; Dalpiaz, D.; Zaccanti, F. Morphological aspects of gonadal morphogenesis in Bufo bufo (Amphibia Anura): Bidder's organ differentiation. Anat. Rec. 2007, 290, 801-813. [CrossRef]

162. Piprek, R.P.; Kloc, M.; Kubiak, J.Z. Bidder's organ-Structure, development and function. Int. J. Dev. Biol. 2014, 58, 819-827. [CrossRef]

163. Abramyan, J.; Wilhelm, D.; Koopman, P.A. Molecular characterization of the Bidder's organ in the cane toad (Bufo marinus). J. Exp. Zool. B Mol. Dev. Evol. 2010, 314, 503-513. [CrossRef]

164. Farias, C.F.; Carvalho-e-Silva, S.P.; De Brito-Gitirana, L. Bidder's organ of Bufo ictericus: A light and electron microscopy analysis. Micron 2002, 33, 673-679. [CrossRef]

165. Pancak-Roessler, M.K.; Norris, D.O. The effects of orchidectomy and gonadotropins on steroidogenesis and oogenesis in Bidder's organs of the toad Bufo woodhousii. J. Exp. Zool. 1991, 260, 323-336. [CrossRef] [PubMed]

166. Silberschmidt Freitas, J.; Franco-Belussi, L.; De Oliveira, C. Morphological and histochemical studies of Bidder's organ in Rhinella schneideri (Amphibia: Anura) males. Ital. J. Zool. 2015, 82, 479-488. [CrossRef]

167. Brown, F.D.; Del Pino, E.M.; Krohne, G. Bidder's organ in the toad Bufo marinus: Effects of orchidectomy on the morphology and expression of lamina-associated polypeptide 2. Dev. Growth Differ. 2002, 44, 527-535. [CrossRef] [PubMed]

168. Zaccanti, F.; Tognato, G. Effects of different doses of diethylstilbestrol dipropionate on the bidder's organ of intact or orchiectomized adult males of Bufo bufo (L). Monit. Zool. Ital. Ital. J. Zool. 1976, 10, 105-117. [CrossRef]

169. Petrini, S.; Zaccanti, F. The Effects of Aromatase and 5 a-Reductase Inhibitors, Antiandrogen, and Sex Steroids on Bidder's Organs Development and Gonadal Differentiation in Bufo bufo Tadpoles. J. Exp. Zool. 1998, 259, 245-259. [CrossRef] 
170. Harms-Marburg, W. Untersuchungen über das Biddersche Organ der männlichen und weiblichen Kröten. I. Mitteilung: Die Morphologie des Bidderschen Organes. Zeitschrift Anatomie Entwicklungsgeschichte 1921, 62, 1-38. [CrossRef]

171. Piprek, R.P.; Pecio, A.; Laskowska-Kaszub, K.; Kloc, M.; Kubiak, J.Z.; Szymura, J.M. Retinoic acid homeostasis regulates meiotic entry in developing anuran gonads and in Bidder's organ through Raldh2 and Cyp26b1 proteins. Mech. Dev. 2013. [CrossRef]

172. Scaia, M.F.; Regueira, E.; Sassone, A.G.; Volonteri, M.C.; Ceballos, N.R. The Bidder's organ of the toad Rhinella arenarum (Amphibia, Anura). Presence of steroidogenic enzymes. J. Exp. Zool. Part A Ecol. Genet. Physiol. 2011, 315A, 439-446. [CrossRef]

173. Stévant, I.; Papaioannou, M.D.; Nef, S. A brief history of sex determination. Mol. Cell. Endocrinol. 2018, 468, 3-10. [CrossRef]

174. Estermann, M.A.; Williams, S.; Hirst, C.E.; Roly, Z.Y.; Serralbo, O.; Adhikari, D.; Powell, D.; Major, A.T.; Smith, C.A. Insights into Gonadal Sex Differentiation Provided by Single-Cell Transcriptomics in the Chicken Embryo. Cell Rep. 2020, $31,107491$. [CrossRef]

175. Czerwinski, M.; Natarajan, A.; Barske, L.; Looger, L.L.; Capel, B. A timecourse analysis of systemic and gonadal effects of temperature on sexual development of the red-eared slider turtle Trachemys scripta elegans. Dev. Biol. 2016, 420, 166-177. [CrossRef]

176. Yatsu, R.; Miyagawa, S.; Kohno, S.; Parrott, B.B.; Yamaguchi, K.; Ogino, Y.; Miyakawa, H.; Lowers, R.H.; Shigenobu, S.; Guillette, L.J.; et al. RNA-seq analysis of the gonadal transcriptome during Alligator mississippiensis temperature-dependent sex determination and differentiation. BMC Genom. 2016, 17, 77. [CrossRef]

177. Piprek, R.P.; Damulewicz, M.; Tassan, J.P.; Kloc, M.; Kubiak, J.Z. Transcriptome profiling reveals male- and female-specific gene expression pattern and novel gene candidates for the control of sex determination and gonad development in Xenopus laevis. Dev. Genes Evol. 2019, 229, 53-72. [CrossRef] [PubMed]

178. Tao, W.; Chen, J.; Tan, D.; Yang, J.; Sun, L.; Wei, J.; Conte, M.A.; Kocher, T.D.; Wang, D. Transcriptome display during tilapia sex determination and differentiation as revealed by RNA-Seq analysis. BMC Genom. 2018, 19, 1-12. [CrossRef] [PubMed]

179. Capel, B. Vertebrate sex determination: Evolutionary plasticity of a fundamental switch. Nat. Rev. Genet. 2017. [CrossRef] [PubMed]

180. Yao, H.H.C.; Capel, B. Temperature, genes, and sex: A comparative view of sex determination in Trachemys scripta and Mus musculus. J. Biochem. 2005, 138, 5-12. [CrossRef]

181. Biscotti, M.A.; Carducci, F.; Barucca, M.; Gerdol, M.; Pallavicini, A.; Schartl, M.; Canapa, A.; Adolfi, M.C. The transcriptome of the newt Cynops orientalis provides new insights into evolution and function of sexual gene networks in sarcopterygians. Sci. Rep. 2020, 10, 1-14. [CrossRef]

182. Crews, D.; Bull, J.J. Mode and tempo in environmental sex determination in vertebrates. Semin. Cell Dev. Biol. 2009, 20, 251-255. [CrossRef]

183. Fujitani, K.; Otomo, A.; Wada, M.; Takamatsu, N.; Ito, M. Sexually dimorphic expression of Dmrt1 and $\gamma \mathrm{H} 2 \mathrm{AX}$ in germ stem cells during gonadal development in Xenopus laevis. FEBS Open Bio 2016, 6, 276-284. [CrossRef]

184. Piprek, R.P.; Damulewicz, M.; Kloc, M.; Kubiak, J.Z. Transcriptome analysis identifies genes involved in sex determination and development of Xenopus laevis gonads. Differentiation 2018, 100, 46-56. [CrossRef]

185. Miura, I.; Ohtani, H.; Ogata, M.; Ezaz, T. Evolutionary Changes in Sensitivity to Hormonally Induced Gonadal Sex Reversal in a Frog Species. Sex. Dev. 2016, 10, 79-90. [CrossRef] [PubMed]

186. Piprek, R.P.; Kolasa, M.; Podkowa, D.; Kloc, M.; Kubiak, J.Z. Transcriptional profiling validates involvement of extracellular matrix and proteinases genes in mouse gonad development. Mech. Dev. 2018, 149, 9-19. [CrossRef] [PubMed]

187. Haselman, J.T.; Olmstead, A.W.; Degitz, S.J. Global gene expression during early differentiation of Xenopus (Silurana) tropicalis gonad tissues. Gen. Comp. Endocrinol. 2016, 214, 103-113. [CrossRef] [PubMed]

188. Piprek, R.P.; Pecio, A.; Laskowska-Kaszub, K.; Kubiak, J.Z.; Szymura, J.M. Sexual dimorphism of AMH, DMRT1 and RSPO1 localization in the developing gonads of six anuran species. Int. J. Dev. Biol. 2013, 57, 871-875. [CrossRef]

189. El Jamil, A.; Kanhoush, R.; Magre, S.; Boizet-Bonhoure, B.; Penrad-Mobayed, M. Sex-specific expression of SOX9 during gonadogenesis in the amphibian Xenopus tropicalis. Dev. Dyn. 2008, 237, 2996-3005. [CrossRef] [PubMed]

190. Dumond, H.; Al-Asaad, I.; Chesnel, A.; Chardard, D.; Boizet-Bonhoure, B.; Flament, S.; Kuntz, S. Temporal and spatial SOX9 expression patterns in the course of gonad development of the caudate amphibian Pleurodeles waltl. J. Exp. Zool. B Mol. Dev. Evol. 2011, 316B, 199-211. [CrossRef] [PubMed]

191. Al-Asaad, I.; Chardard, D.; Di Clemente, N.; Picard, J.Y.; Dumond, H.; Chesnel, A.; Flament, S. Müllerian inhibiting substance in the caudate amphibian Pleurodeles waltl. Endocrinology 2013, 154, 3931-3936. [CrossRef] [PubMed]

192. Kuntz, S.; Chesnel, A.; Duterque-Coquillaud, M.; Grillier-Vuissoz, I.; Callier, M.; Dournon, C.; Flament, S.; Chardard, D. Differential expression of P450 aromatase during gonadal sex differentiation and sex reversal of the newt Pleurodeles waltl. J. Steroid Biochem. Mol. Biol. 2003, 84, 89-100. [CrossRef]

193. Osawa, N.; Oshima, Y.; Nakamura, M. Molecular cloning of Dmrt1 and its expression in the gonad of Xenopus. Zoolog. Sci. 2005, 22, 681-687. [CrossRef] [PubMed]

194. Shibata, K.; Takase, M.; Nakamura, M. The Dmrt1 expression in sex-reversed gonads of amphibians. Gen. Comp. Endocrinol. 2002, 127, 232-241. [PubMed]

195. Sakata, N.; Miyazaki, K.; Wakahara, M. Up-regulation of P450arom and down-regulation of Dmrt-1 genes in the temperaturedependent sex reversal from genetic males to phenotypic females in a salamander. Dev. Genes Evol. 2006, 216, 224-228. [CrossRef] 
196. Mawaribuchi, S.; Ikeda, N.; Fujitani, K.; Ito, Y.; Onuma, Y.; Komiya, T.; Takamatsu, N.; Ito, M. Cell-mass structures expressing the aromatase gene Cyp19a1 lead to ovarian cavities in Xenopus laevis. Endocrinology 2014, 155, 3996-4005. [CrossRef] [PubMed]

197. Maruo, K.; Suda, M.; Yokoyama, S.; Oshima, Y.; Nakamura, M. Steroidogenic gene expression during sex determination in the frog Rana rugosa. Gen. Comp. Endocrinol. 2008, 158, 87-94. [CrossRef]

198. Miura, I.; Kitamoto, H.; Koizumi, Y.; Ogata, M.; Sasaki, K. An X-linked body color gene of the frog Rana rugosa and its application to the molecular analysis of gonadal sex differentiation. Sex. Dev. 2011, 5, 250-258. [CrossRef] [PubMed]

199. Sakurai, N.; Maruo, K.; Haraguchi, S.; Uno, Y.; Oshima, Y.; Tsutsui, K.; Matsuda, Y.; Do Rego, J.L.; Pelletier, G.; Vaudry, H.; et al. Immunohistochemical detection and biological activities of CYP17 (P450c17) in the indifferent gonad of the frog Rana rugosa. J. Steroid Biochem. Mol. Biol. 2008, 112, 5-12. [CrossRef] [PubMed]

200. Iwade, R.; Maruo, K.; Okada, G.; Nakamura, M. Elevated expression of P450c17 (CYP17) during testicular formation in the frog. Gen. Comp. Endocrinol. 2008, 155, 79-87. [CrossRef]

201. Kelley, D.B. Sexual differentiation in Xenopus laevis. In The Biology of Xenopus; Tiinsely, R., Kobel, H.R., Eds.; Oxford University Press: Oxford, UK, 1996; pp. 143-176.

202. Oshima, Y.; Uno, Y.; Matsuda, Y.; Kobayashi, T.; Nakamura, M. Molecular cloning and gene expression of Foxl2 in the frog Rana rugosa. Gen. Comp. Endocrinol. 2008, 159, 170-177. [CrossRef]

203. Zhang, T.; Oatley, J.; Bardwell, V.J.; Zarkower, D. DMRT1 Is Required for Mouse Spermatogonial Stem Cell Maintenance and Replenishment. PLoS Genet. 2016, 12, 1-18. [CrossRef]

204. Dranow, D.B.; Tucker, R.P.; Draper, B.W. Germ cells are required to maintain a stable sexual phenotype in adult zebrafish. Dev. Biol. 2013, 376, 43-50. [CrossRef]

205. Dranow, D.B.; Hu, K.; Bird, A.M.; Lawry, S.T.; Adams, M.T.; Sanchez, A.; Amatruda, J.F.; Draper, B.W. Bmp15 Is an OocyteProduced Signal Required for Maintenance of the Adult Female Sexual Phenotype in Zebrafish. PLoS Genet. 2016, 12, 1-24. [CrossRef]

206. Bögi, C.; Levy, G.; Lutz, I.; Kloas, W. Functional genomics and sexual differentiation in amphibians. Comp. Biochem. Physiol. B Biochem. Mol. Biol. 2002, 133, 559-570. [CrossRef]

207. Morrish, B.C.; Sinclair, A.H. Vertebrate sex determination: Many means to an end. Reproduction 2002, 124, 447-457. [CrossRef] [PubMed]

208. Takase, M.; Noguchi, S.; Nakamura, M. Two Sox9 messenger RNA isoforms: Isolation of cDNAs and their expression during gonadal development in the frog Rana rugosa. FEBS Lett. 2000, 466, 249-254. [CrossRef]

209. Abramyan, J.; Feng, C.W.; Koopman, P.A. Cloning and expression of candidate sexual development genes in the cane toad (Bufo marinus). Dev. Dyn. 2009, 238, 2430-2441. [CrossRef]

210. Nakamura, S.; Watakabe, I.; Nishimura, T.; Toyoda, A.; Taniguchi, Y.; Tanaka, M. Analysis of medaka sox 9 orthologue reveals a conserved role in germ cell maintenance. PLoS ONE 2012, 7, e29982. [CrossRef] [PubMed]

211. De Santa Barbara, P.; Bonneaud, N.; Boizet, B.; Desclozeaux, M.; Moniot, B.; Sudbeck, P.; Scherer, G.; Poulat, F.; Berta, P. Direct interaction of SRY-related protein SOX9 and steroidogenic factor 1 regulates transcription of the human anti-Müllerian hormone gene. Mol. Cell. Biol. 1998, 18, 6653-6665. [CrossRef]

212. Oreal, E.; Pieau, C.; Mattei, M.G.; Josso, N.; Picard, J.-Y.; Carré-Eusèbe, D.; Magre, S. Early expression of $A M H$ in chicken embryonic gonads precedes testicular SOX9 expression. Dev. Dyn. 1998, 212, 522-532. [CrossRef]

213. Jansson, E.; Mattsson, A.; Goldstone, J.; Berg, C. Sex-dependent expression of anti-Müllerian hormone (amh) and amh receptor 2 during sex organ differentiation and characterization of the Müllerian duct development in Xenopus tropicalis. Gen. Comp. Endocrinol. 2016, 229, 132-144. [CrossRef]

214. Kodama, M.; Suda, M.; Sakamoto, D.; Iwasaki, T.; Matsuo, Y.; Uno, Y.; Matsuda, Y.; Nakamura, Y.; Maekawa, S.; Katsu, Y.; et al. Molecular cloning and characterization of anti-Müllerian hormone (AMH) from the Japanese wrinkled frog, Rana rugosa. Endocrinology 2015, 156, 1914-1923. [CrossRef] [PubMed]

215. Morinaga, C.; Saito, D.; Nakamura, S.; Sasaki, T.; Asakawa, S.; Shimizu, N. The hotei mutation of medaka in the anti-Müllerian hormone receptor causes the dysregulation of germ cell and sexual development. Proc. Natl. Acad. Sci. USA 2007, 104, 9691-9696. [CrossRef] [PubMed]

216. Shiraishi, E.; Yoshinaga, N.; Miura, T.; Yokoi, H.; Wakamatsu, Y.; Abe, S.I.; Kitano, T. Müllerian inhibiting substance is required for germ cell proliferation during early gonadal differentiation in medaka (Oryzias latipes). Endocrinology 2008, 149, 1813-1819. [CrossRef] [PubMed]

217. Nakamura, S.; Watakabe, I.; Nishimura, T.; Picard, J.Y.; Toyoda, A.; Taniguchi, Y.; di Clemente, N.; Tanaka, M. Hyperproliferation of mitotically active germ cells due to defective anti-Müllerian hormone signaling mediates sex reversal in medaka. Development 2012, 139, 2283-2287. [CrossRef] [PubMed]

218. Dumond, H.; Maufroid, J.-P.; Ko, C.-I.; Chardard, D.; Chesnel, A.; Flament, S.A. Freemartin in the Amphibian Pleurodeles waltl: Parabiosis Between Individuals From Opposite Sex Triggers Both Germ and Somatic Cells Alterations During Female Gonad Development. Mol. Reprod. Dev. 2008, 75, 439-449. [CrossRef]

219. Adolfi, M.C.; Nakajima, R.T.; Nóbrega, R.H.; Schartl, M. Intersex, Hermaphroditism, and Gonadal Plasticity in Vertebrates: Evolution of the Müllerian Duct and Amh/Amhr2 Signaling. Annu. Rev. Anim. Biosci. 2019, 7, 149-172. [CrossRef] [PubMed] 